\title{
Race War Flares Up: Chicago's Swedish Press, the Great Migration, and the 1919 Riots
}

\section{Ulf Jonas Björk}

Indiana University at Indianapolis

\begin{abstract}
This study of the three large Swedish-language weeklies in Chicago examines how they covered the city's African-American community during the latter half of the 1910s, a time when blacks migrated to the North in huge numbers. In Chicago, the result was that the African-American population almost tripled between 1910 and 1920. Little of that was visible in the columns of the weeklies, however, with only a handful of items telling readers that blacks were arriving in record numbers. What news there was about African-Americans, moreover, tended to portray them as criminals. Consequently, the riots that shook Chicago in late July 1919 seemed to take the editors of the weeklies by surprise. A major explanation for the Swedish weeklies' coverage was that they relied almost exclusively on the city's English-language dailies for news that did not concern their own ethnic group and thus mirrored the negative way the dailies portrayed African-Americans.
\end{abstract}

Keywords: immigrant press, Swedish-Americans, African-Americans, race relations, ethnic images

On July 31, 1919, Svenska Amerikanaren, a Swedish-language weekly in Chicago, informed its readers that riots had gripped the city the previous week, leaving at least 20 dead. What had occurred, the paper explained, was "a terrible and bloody race war between whites and blacks." ${ }^{1}$ How America's immigrant press dealt with race relations and the tension and violence that they created has been largely ignored by historians, a reflec- 
tion of what Robert Zecker calls a broader tendency that "effaced considerations of race from the immigrant narrative."2 As Zecker's study of the Slovak-American press showed, however, news items that touched on race relations in America, such as accounts of lynchings, surfaced with fairly regular frequency in the papers that Slovak immigrants read. Discussions of the Swedish-language press, such Ulf Beijbom's Swedes in Chicago and the edited volume Swedish-American Life in Chicago have tended to focus on how the papers dealt with the immigrant community it served. Finis Herbert Capps' book From Isolationism to Involvement and Edward Burton's The Swedish-American Press and the Vietnam War in turn addressed how the Swedish immigrant press dealt with U.S. foreign policy. ${ }^{3}$

With Zecker's work in mind, this article discusses the coverage of African-Americans in three large Swedish-language weeklies in Chicago, the aforementioned Svenska Amerikanaren (The Swedish-American) and its two main rivals, Svenska Tribunen-Nyheter (The Swedish Tribune-News) and Svenska Kuriren (The Swedish Courier), to examine how the Swedish immigrant press dealt with race. The period under study is 1915-1920, when Chicago's black population rose dramatically due to the Great Migration, which saw African-Americans move from the rural South to the urban North. News pages as well as editorials were examined for all issues of the three papers. ${ }^{4}$

Two basic questions guided the study. First, how were African-Americans portrayed, and to what extent did the coverage of blacks in Chicago's Swedish press reflect attitudes and stereotypes held by native-born white Chicagoans? Second, did the three newspapers give their readers a sense of the huge influx of African-Americans that almost tripled the number of blacks in Chicago between 1910 and 1920 and the subsequent tensions and challenges produced by that influx? First, however, it is necessary to pro-

Zecker, Race and America's Immigrant Press: How the Slovaks Were Taught to Think like White People (New York: Continuum, 2011), 2.

3 Beijbom, Swedes in Chicago: A Demographic and Social Study of the 1846-1880 Immigration (Stockholm: Läromedelsförlagen, 1971); Philip J. Anderson and Dag Blanck, Swedish-American Life in Chicago: Cultural and Urban Aspects of an Immigrant People (Urbana: University of Illinois Press, 1992); Capps, From Isolationism to involvement: The Swedish Immigrant Press in America, 1914-1945 (Chicago: Swedish Pioneer Historical Society, 1966); Burton, The Swedish-American Press and the Vietnam War (Göteborg: Department of History, Göteborg University, 2003).

4 Microfilm copies of the newspaper were obtained through interlibrary loan from the Swenson Swedish Immigration Research Center in Rock Island, Ill., the largest repository of Swedish-language U.S. publications in the United States. 
vide some context for the three newspapers and their readers.

\section{Chicago Swedes: Numbers and Backgrounds}

From the mid-1840s until 1910, almost a million Swedes left their homeland for the United States. ${ }^{5}$ Although most of them came from rural settings and had the intention of becoming farmers in America, many found themselves settling in cities once they arrived in the United States. Because they tended to favor destinations in the Upper Midwest, Chicago soon emerged as a hub for Swedish immigrants. By 1900, the city's Swedish-born inhabitants and their American-born children had reached 150,000, making Chicago the second largest "Swedish" city in the world, surpassed only by Sweden's capital, Stockholm. Chicago's Swedish-born population peaked at 63,000 in 1910, making Swedes the fifth largest immigrant group in the city. ${ }^{6}$

Among the challenges that the newcomers from Sweden faced was finding themselves in a truly multiethnic society: according to the 1910 U.S. Census, there were more than 25 ethnic and immigrant groups in Chicago, and they made up 36 percent of the city's population. By contrast, the society that the Swedes had left was thoroughly homogenous as to ethnicity. A total of 21,000 Swedish residents with a foreign background were recorded in Sweden's census record for 1910, a figure that amounted to 0.4 percent of the country's total population. Immigrants to Sweden, most of whom were fellow Scandinavians or Swedes returning from America, constituted 0.2 percent. Homogeneity also extended to religion: those not affiliated with the state Lutheran church amounted to 0.3 percent of the population. ${ }^{7}$ Living next to people of different ethnicities and religious faiths in new surroundings was thus a bewildering experience for Swedes settling in Chicago.

\section{Chicago's Swedish-Language Newspapers}

5 Cecilia Thorborg, "Massutvandring till Amerika slag mot befolkningen," http://www.scb.se/sv_/Hittastatistik/Artiklar/Massutvandring-till-Amerika-slag-mot-befolkningen/, accessed 15 May 2017.

6 U.S. Department of Commerce, Bureau of the Census, Thirteenth Census of the United States, 1910, vol. 2, 512; Erik Dregni, Vikings in the Attic: In Search of Nordic America (Minneapolis, MN: University of Minnesota Press, 2011), 11.

7 Statistisk årsbok för Sverige (Stockholm: Kungl. Statistiska Centralbyrån, 1914), 12, 16, 42; adding indigenous peoples-Sami and Finns - the figure for those with non-Swedish backgrounds rises to 0.6 percent. 
The large Swedish population in Chicago made the city a fertile ground for Swedish-language publications. From the late 1850s, when the first such publishing ventures were launched, to the end of the 1910s, more than 25 weekly newspapers were started in Chicago, making it the capital of Swedish-language publishing in America ${ }^{8}$ Proof of Chicago's preeminence in the Swedish-American newspaper press was that editors there commanded higher salaries than anywhere else. The editorial staffs were also bigger: five editors at Svenska Tribunen-Nyheter, four at Svenska Amerikanaren, and three at Svenska Kuriren. ${ }^{9}$

These three weeklies were giants of the Swedish-American press, as their reported 1914 circulations - 75,847 for Svenska Amerikanaren, 65,006 for Svenska Tribunen-Nyheter and 42,400 for Svenska Kuriren-dwarfed the average Swedish-language newspaper's print run of a few thousand copies. ${ }^{10}$ They had aspirations to be national in their reach, and there are indications that they were. Letters to the editor in Svenska Amerikanaren were sent in from across the United States, for instance, while the editor of Nya Världen in Bellingham, Washington, explained in 1907 that he focused on local news because "[m]ost of our readers take an Eastern paper as well.""11 The desire to appeal to readers on a national level is evident in the ample space that all three papers devoted to news from Sweden, news about Swedish immigrants across America, and "American" news with national impact, such as the proceedings of U.S. Congress. ${ }^{12}$

Based in Chicago, the three papers also covered their hometown. Unless major local events such as the 1919 riots occurred and merited front-page treatment, local news could be found in the Chicago department, toward the end of each issue. A great deal of what appeared in that department dealt with Swedish Chicago: activities of immigrant institutions such as churches and societies and accounts of individual immigrants. Municipal news was

8 Lilly Setterdahl, Swedish-American Newspapers (Rock Island, IL: Augustana College Library, 1981), 8-13.

9 Old Crow, "Som andra se oss," Bläckfisken (Chicago: Svenska Journalistförbundet i Amerika, 1921), 18690; Ernst Skarstedt to Conrad Skarstedt, 20 April 1915, Conrad Skarstedt papers, Riksföreningen Sverigekontakt, Göteborg, Sweden.

10 N.W. Ayer \& Son's American Newspaper Annual and Directory (Philadelphia: N.W. Ayer \& Son, 1915), 1280 .

11 Nya Världen, 8 February 1907, 3.

12 Their content broadly reflected that of immigrant newspapers in general, see Jerzy Zubricki, "The Role of the Foreign-Language Press in Migrant Integration," in Jean Folkerts, ed., Media Voices: An Historical Perspective (New York: Macmillan Publishing Company, 1992), 274-82. 
also a regular feature: items emanating from City Hall, the Chicago Police Department, and local courts, as well as reports of traffic accidents and comments about the weather. Next to these two major categories, items about other ethnic and immigrant groups occasionally found their way into the Chicago Department.

\section{Ethnic Coverage}

To ascertain what kind of ethnic news the three papers published, every issue of each paper was examined from 1 June 1915 to 31 December 1920. For an item to be included, the paper in which it appeared had to identify a person as a member of an ethnic group, such as "Negro," "Italian," or "Polish." The results show that the three papers took only a scant interest in ethnic groups that were not Scandinavian: from July 1915 to July 1919, Svenska Amerikanaren and Svenska Kuriren published 12 items per year about non-Scandinavians and Svenska Tribunen-Nyheter only 3. (This seeming lack of interest was in sharp contrast to a five-year-period 10 years earlier, when the corresponding figures were 54 for Amerikanaren, 49 for Kuriren, and 24 for Tribunen-Nyheter.$^{13}$ )

Among ethnic groups, African-Americans accounted for the largest share in Svenska Amerikanaren and Svenska Tribunen-Nyheter, at 46 percent for both. The next largest share in the two papers was that of Italians, 38 and 31 percent, respectively. Italians received more attention-a share of 28 percent-in Svenska Kuriren than blacks, who accounted for 19 percent of all items in that paper. More ethnically diverse in its outlook than the other two, Kuriren also published a fairly large number of items about immigrants from China (13 percent) and Greece (11 percent).

Just as the total amount of news in the three papers had been larger in the first decade of the twentieth century, so had the number of items about African-Americans, who accounted for the largest share in all of the papers from 1904 to 1908: 34 percent in Tribunen-Nyheter and 26 percent in Kuriren and Amerikanaren. The seeming loss of interest in ethnic groups overall and in African-Americans in the 1915-1919 period is somewhat puzzling, particularly in the case of blacks, whose numbers increased significantly in Chicago in the latter half of the 1910s. ${ }^{14}$ 


\section{African-Americans in Chicago and the Great Migration}

The 150-percent growth of Chicago's African-American population between the 1910 and 1920 censuses, from 44,103 to 109,458, was a result of what is known as the Great Migration, of blacks moving in great numbers from the rural South to the urban North. They made the move because of the job opportunities opened up by World War I. The conflict both produced boom times for U.S. industry as orders increased dramatically from the belligerents in Europe and all but choked off the steady influx of European immigrants on whom employers had relied for factory labor. ${ }^{15}$ In its investigation of the 1919 Chicago Riots, the Chicago Commission on Race Relations estimated that half-a-million African-Americans left the South for the North between 1916 and 1918; in an 18-month period in 1917-1918, 50,000 were counted as arriving in Chicago. ${ }^{16}$

As the Commission found out, the newcomers had made the move in search of higher wages and in hopes of escaping segregation and racial injustice. What they found in Chicago, however, was an environment with altogether different challenges, such as racial tensions in the workplace and segregated and substandard housing. As William Tuttle has pointed out, competition for jobs between black and white workers had a long history in Chicago that dated back to the 1890s, when, for the first time AfricanAmericans had been brought in as strikebreakers in the stockyards. Their return in that role in 1904 and 1905 further reinforced workplace racial tensions, and white hostility toward blacks also started to extend beyond stockyards and factories. The complex relationship that blacks had with labor unions, which included unfamiliarity with their role, unwillingness to join, and reluctance of white union members to let them in, further exacerbated relations between white and black workers and led to several violent confrontations in the years leading up to the 1919 riots. ${ }^{17}$

and less to the outside world as immigrant communities mature, but it is tenuous to make that case for Swedish Chicago as early as the 1910s, as the author's studies of other Swedish-language papers over longer time periods suggest that such a shift in content did not occur until the 1930s. Marion Marzolf, The Danish-Language Press in America (New York: Arno Press, 1979).

15 William M. Tuttle, Jr., "Labor Conflict and Racial Violence: The Black Worker in Chicago, 1894-1919," Labor History 10 (3, 1968):418.

16 The Chicago Commission on Race Relations, The Negro in Chicago: A Study of Race Relations and a Race Riot (Chicago: University of Chicago Press, 1922, reprint ed., Arno Press and the New York Times, 1968), 79, 83-84.

17 Tuttle, "Labor Conflict" 1968, 425-32. 
When it came to housing, African-American migrants to Chicago found themselves confined to the so-called "black belt," a narrow area on the city's Southside. Even before the influx during the Great Migration began in earnest, one observer claimed that there was no other neighborhood in the city that was "so conspicuously dilapidated as the black belt," where "leaking roofs, doors without hinges, broken windows, insanitary plumbing, rotting floors" were in abundant evidence. ${ }^{18}$ As the wave of newcomers sought housing in the late 1910s, they had virtually no other option than the black belt. Overcrowding soon became an issue. Fully aware that their tenants had no choice as to where to live, landlords raised rents and turned a deaf ear to pleas for repairs. African-Americans who attempted to move out of the black belt were often threatened with violence, and some of them even had their houses bombed.

\section{Covering African-Americans}

As is evident from the small number of news items in the three Swedish weeklies, very little of this volatile situation was communicated to Swedish-American readers. Although news items about African-Americans far outnumbered those about other ethnic groups, they were still so few in absolute numbers that they conveyed only scarce glimpses of Chicago's black population. Those glimpses, moreover, were almost entirely negative. When African-Americans surfaced in the columns of the three Swedish newspapers, it was as criminals: robbers, burglars and murderers.

In July 1915, for instance, Svenska Amerikanaren told its readers "a large Negro" had been arrested in Jackson Park for robbery. He had been snatching purses from women, who if they resisted or called for help were beaten with the butt of his revolver. ${ }^{19}$ Reaffirming mental images of African-Americans as dangerous, the paper concluded by noting that "[w]hen the negro was arrested, he was armed with a revolver and a razor." A few months later, Svenska Tribunen-Nyheter reported that "a young Negro" had "labored in vain" when he attempted to break into a stockbroker's home but was spotted by a family member who called out for help. After trying to

18 William M. Tuttle, Jr., "Contested Neighborhoods and Racial Violence: Prelude to the Chicago Riot of 1919," The Journal of Negro History 55 (4, Oct. 1970), 270.

19 “Gripen rånare," SA, 29 July 1915, 15. 
escape, the paper related, "the Negro was put in the slammer." ${ }^{20}$ In February 1916, a woman had found herself "at the mercy of a black robber," according to Svenska Amerikanaren, when an African-American man had taken her purse from her, and eight months later a teamster was robbed in his office by "brazen darkies" who started shooting when he tried to stop them. ${ }^{21}$

As the above stories suggest, part of the narrative about blacks in the three papers was that they were inherently violent. In September 1915, Svenska Amerikanaren reported that two boys had made a "[h]orrible discovery' when they came upon a trunk. Inside was the body of an AfricanAmerican woman, her throat cut from ear to ear, and police investigations had revealed that she was "the wife or mistress of the negro E.W. Bragg" who was assumed to be the perpetrator. ${ }^{22}$ Toward the end of 1915, Amerikanaren's readers were informed that a retired Chicago police officer had been robbed by a black man who had shot and killed the officer when he reached for his gun. ${ }^{23}$

In July 1916, both Svenska Amerikanaren and Svenska Kuriren ran items about a black couple who had barricaded themselves inside an apartment building and started firing shots at their neighbors. "An insane Negro and his equally insane wife declared war on humanity in its entirety last Tuesday morning," claimed Kuriren, and then went on to describe how 10,000 spectators had been drawn to "the theatre of war" by the sounds of gunfire. Identifying the man by name in the first few lines of the story, the paper referred to him as "the Negro" throughout the rest of the piece, ending by explaining that neighbors thought he suffered from "religious madness" and had been "raving about the resurrection of a great Negro kingdom in Africa." 24 Slightly less bombastic in its coverage of "the deed of a madman," Amerikanaren also noted the ethnicity of the shooter in the first sentence. ${ }^{25}$

Kuriren's account of the shootout followed what was a general pattern in news items about African-Americans in the three papers. Members of other ethnic groups were usually identified by their origin once and then referred to by their last name; blacks, on the other hand, were repeatedly referred to as negern (the Negro) and occasionally as svartingen (the darkie). ${ }^{26}$

\footnotetext{
20 “Besvärade sig förgäves," Svenska Tribunen-Nyheter (hereafter, STN), 14 September 1915, 16.

21 “Tre svarta rånare," SA, 23 November 1916, 15; "I svarta röfvarehänder," SA, 3 February 1916, 14.

22 "Hemskt fynd," SA, 23 September, 1915, 14.

23 “Rånmord af neger," $S A, 30$ December 1915, 14.

24 “En galen neger," Svenska Kuriren (hereafter, SK), 20 July 1916, 11.

25 "En vansinnigs dåd," SA, 20 July 1916, 14.
}

26 According to studies of Swedish-American language use, neger (Negro) was regarded as a "standard" term 
In August 1916, Svenska Kuriren told its readers that "a terrible waste of powder and ball-almost like in the world war" had occurred on the Southside after two black longshoremen fell out over a game of dice; luckily, their aim had been so bad that nobody had been hit, and police had arrived fairly soon to arrest the combatants. ${ }^{27}$ In July 1917, Svenska Amerikanaren published a lengthy item about an altercation aboard a streetcar that involved "a brazen darkie" named Clarence Kelley, "a beanpole, stoutly built, who was on the warpath from the start." Fred Hohing, a white businessman, had passed through the car and happened to bump into Kelley. "A moment later, the Negro was on his feet, followed H. and showered him with abuse while pulling out a large knife and threatening to chop up Hohing." Passengers quickly surrounded and subdued Kelley, but he lunged at an officer when delivered to police at the next stop and was shot and killed..$^{28}$ The association of blacks with crime was also evident in several items about African-Americans either awaiting execution or having been executed. ${ }^{29}$

Even when no criminal activity was implied, items about African-Americans tended to have a derogatory tone. To the story of an elderly man who had had the foresight to save money for his old age, Svenska Amerikanaren added the off-hand comment that "care about tomorrow is not exactly a distinguishing trait of the race to which he belongs." ${ }^{30}$ Svenska Kuriren devoted a fairly long item to the story of how five men, "not ravenous but thirsty," had entered a salon closed for Sunday through a door that the establishment's African-American janitor, Sam (who was not given a last name) had left open. Confronted by what he thought were robbers, the janitor had not displayed a great deal of courage:

Sam was shaking like a leaf. After he been shaking for a while, he ran like a hunted deer out the door and called for the police. ${ }^{31}$

Items that linked African-Americans to criminal activity in the late 1910s continued a long-time pattern. Between 1904 and 1908, the three papers

of reference for African-Americans, while svarting (literally "blackie," but usually translated as "darkie") was "slightly derisive," see Siiri Sahlman-Karlsson, Specimens of American Finnish," Acta Universitatis Upsaliensis. Studia uralica at Altaica Upsaliensia 11 (Umeå, Sweden: s.n, 1976), 88.

27 "Ett förfärligt ödslande med kulor och krut," SK, 31 August 1916, 11.

28 "En fräck svarting," SA, 12 July 1917, 14.

29 "En ny afrättning," STN, 7 September 1915, 16; "Galgenfrist," SA, 6 July 1916, 14.

30 "Den som spar han har nå'nting på gamla da'r," SA, 15 May 1919, 10.

31 "Icke roflystna, bara törstiga," $S K, 4$ May 1916, 10. 
discussed here had covered blacks in Chicago in the same manner, publishing virtually no news that was not negative in character. In a 1906 editorial, Svenska Amerikanaren had even suggested that criminality was all but an inherent trait. Responding to a speech where an African-American bishop had warned that "the white man cannot trample the black man under foot and expect to do so unimpeded," the Swedish paper said the clergyman was mistaken if he thought that whites were the enemies of blacks:

[T] he white race only dislikes the crimes that darkies commit and is unhappy about their loose morals and their inclination to steal and rape. An honest, peaceful Negro is never regarded as an enemy by the whites - least of all here in the northern and northwestern states. ${ }^{32}$

\section{Inter-Ethnic Encounters}

Interaction between African-Americans and Swedes was portrayed exclusively as involving crime, with blacks depicted as a threat. A Swedish maid in Evanston had been "at the mercy of a darkie," reported Svenska Amerikanaren in February 2017, when a "colored robber" had accosted her, but her cries for help had scared him off..$^{33}$ Two months later, the paper told its readers that police had been requested to search for a 21-year-old Swede who had disappeared from his home in Oak Park. His family claimed they suspected he had been "abducted by a Negro and is now kept as a captive in Buffalo, N.Y." to keep him from testifying in a case against a black woman in the city's Morals Court. ${ }^{34}$

The other two weeklies ran similarly alarming stories. Svenska TribunenNyheter's readers found out in early 1917 that a fellow Swedish immigrant had been "attacked and robbed by a couple of Negroes" only a few blocks from his Bridgeport home. ${ }^{35}$ An item in Svenska Kuriren related how a Swedish woman in Logan Park had been "scared nearly to death" when she was headed home with an armful of parcels and "was stopped by a Negro who threatened her with a gun." She had fainted on the spot and was unconscious when help arrived. ${ }^{36}$ One of her countrywomen reacted

32 “När negrerna hota," SA, 14 August 1906, 6.

33 "I svartingens våld," SA, 22 February 1917, 15.

34 “Bortstulen af neger," $S A, 12$ April 1917, 14.

35 “Öfverfallen," STN, 30 January 1917, 8.

36 “Nära nog ihjelskrämd," SK, 24 February 1916, 10. 
in a different way in late 1916 when facing a robber. According to Svenska Amerikanaren, as a black man had grabbed her purse, she had "planted her little fist on the bald head of the darkie, who fell to the ground" and she was about "to put her three-inch heel in one of the Negro's eyes" when he got back on his feet and ran off, taking her purse with him. ${ }^{37}$

Some items about Swedish-American encounters with blacks had a fatal outcome. Readers of both Kuriren and Amerikanaren found out in early 1917 that a Swedish tinsmith on his way home from work had been "murdered by a Negro" who had fired three shots, the first of which killed the victim. When the shooter did not find any money in the dead man's pockets, he became enraged and crushed the dead man's skull with the butt of his gun. ${ }^{38}$

The perception that African-Americans were violent in an almost inexplicable way also surfaced in items where encounters between blacks and Swedes did not involve robbery. A Swedish Pullman conductor had been stabbed in a railroad car and seriously wounded, reported Tribunen-Nyheter in September 2016, and the attacker was a black porter who "for reasons unknown had become upset" with him. ${ }^{39}$

In May 1917, both Amerikanaren and Tribunen-Nyheter recounted how Chicago Swede Oscar Lindström had been shot in the intestines when a quarrel had erupted between an unidentified African-American man and other passengers on a streetcar. While Tribunen-Nyheter referred to the shooter's race only in the opening paragraph, subsequently calling him 'the gunman," Amerikanaren followed the pattern discussed above:

Space was scarce, and that was probably why there was an exchange of words between Lindström and the Negro. The Negro suddenly pulled a gun out of his pocket and shot Lindström in the stomach. Before anyone could apprehend the Negro, he pulled open the door and escaped. ${ }^{40}$

\section{Sensing Tension}

Beyond this string of news of seemingly random crimes, the three papers did, on occasion, provide their readers with a glimpse of the changes wrought by the Great Migration. As an example, the item about the De-

37 "Snabb, men ej stark nog," SA, 30 November 1916, 14.

38 Svenska Kuriren and Svenska Amerikanaren published the same version of the story, a week apart; "Mördad af en neger," SK, 28 December 1916, 11; “Mördad af en neger," SA 4 January 1917, 15.

39 "För ett brutalt öfverfall," STN, 26 September 1916, 8.

40 “Skjuten och svårt sårad,” SA, 31 May 1917, 14; “Ett blodigt uppträde," STN, 29 May 1917, 16. 
cember 1917 murder of the Swedish tinsmith included the information that the robber was "one of those who had been brought here from the South to work at the meat-packing firm Wilson \& Co. because there are not enough white workers in this city." 41

Svenska Tribunen-Nyheter, the paper that was the least inclined to run items about other ethnic and immigrant groups, nonetheless provided slightly more contextual information about the African-American influx into Chicago than its rivals. Noting that federal estimates of the city's population were disputed by local authorities, the Swedish paper stressed that "[i]t is a fact that the city's population has notably increased in the last year compared to the previous one, mainly because of the large migration of Negroes from the Southern states." 42 In the same issue, the paper hinted at the tension caused by black migration when it came to housing:

The large migration of Negroes to the several parts of the city, particularly the Kenwood area, is not at all viewed kindly by some property owners, as the white population customarily prefer to move away from areas when the Negroes become too numerous there. Because the blacks in some cases act rowdily, particularly when they have failed in their attempts to find work, it is not particularly pleasant for the whites to have them as neighbors, which is why their moving away perhaps is justified." 43

Local authorities had taken a rather cavalier attitude toward the issue, claimed Tribunen-Nyheter, and would react only if unrest seemed imminent. The paper worried about the upcoming winter, predicting that unemployment would rise, and with it "the hardships of the black population." A month later, Svenska Tribunen-Nyheter commented on a request from the city's public health commissioner for funds to fight smallpox to the effect that he attributed the fourfold increase of smallpox cases compared with 1916 to "the great migration of Negroes from the South," as 161 of the 218 cases were "in the Negro district." 44

Svenska Kuriren touched on segregation and other housing issues only once, in a lengthy item published in March 1917. It noted that the migration was due to recruitment of African-Americans carried out by large employers such as the stockyards and related how the mass numbers of newcom-

\footnotetext{
41 "Mördad af en neger."

42 “Chicagos invånarantal," STN, 17 July 1917, 16.

43 “Den story inflyttningen af negrer," STN, 17 July 1917, 16.

44 “Smittkoppornas talrikhet," STN, 14 August 1917, 16.
} 
ers $-10,000$ workers and their families in the previous two weeks - had started to worry public health officials. The new arrivals were lacking in cleanliness and "do no pay any mind to hygiene," and they lived in "hovels" on the Southside, often a dozen to a room. Comparing long-time black residents of Chicago and the Southerners, "the class difference is at last as great among blacks as among whites," Kuriren claimed, and the established black community regarded the recent migrants as "rabble." 45

While Kuriren and Tribunen-Nyheter inserted editorial comments and explanations into news items, Svenska Amerikanaren chose the editorial page for its only comment on the Great Migration. The same week that Kuriren wrote about crowded housing, Amerikanaren brought up the same issue in a piece entitled "The Black Peril":

The black peril consists of the Negro migration from the South. Several large industrial corporation have recruited masses of ignorant Negroes from the South to replace the white worker here or at least fill the gaps that have opened since mass emigration from Europe ceased due to the war. ${ }^{46}$

Noting that the migrants numbered in the tens of thousands in the last two years alone, the paper went on to argue why their influx constituted a peril:

That the Negroes have come here in large numbers is in itself a danger to the white worker, but the real danger is in their living conditions, which leave much to be desired in terms of sanitation, particularly as they cannot with the best will in the world obtain proper accommodations. The old dilapidated shacks in "the black belt," in the vicinity of $31^{\text {st }}$ and State sts., have now been vacated by their former inhabitants to make room for the newcomers, who have a lower level of education. ${ }^{47}$

In the belt, claimed Amerikanaren, people lived 8-10 to a room, which made them susceptible to diseases like tuberculosis.

\section{An Ominous Portent in East St. Louis}

Toward the end of the 1910s, discreet events suggested mounting tensions as a result of the African-American influx, and they were hard to ignore

\footnotetext{
45 “Negerinvandringen från sydstaterna," SK, 22 March 1917, 10.

46 “Den svarta faran," SA, 22 March 1917, 4.

47 "Den svarta faran."
} 
even for white immigrant papers that seemed otherwise indifferent to Chicago's black population. One such event was the outbreak of race riots in East St. Louis in July 1917, unrest that killed 40 African-Americans and 8 whites. All three papers gave the riots front-page coverage. Svenska Tribunen-Nyheter labeled them a "race war" and declared that the July events surpassed the unrest that had erupted in the same city earlier in the year. ${ }^{48}$ Svenska Kuriren used the term "civil war" in its headline and characterized what had happened as "a bloodbath against Negroes," noting that state militia were accused not only of turning a blind eye to attacks on blacks but also participating in them..$^{49}$ In its Chicago department, the paper quoted a local labor leader to the effect that competition between whites and blacks in the labor market lay behind the riots and that something similar might soon happen in Chicago. ${ }^{50}$

Svenska Amerikanaren added "massacre" to "bloodbath" and "race war" in its coverage. In passionate terms it described how white women had taken part in "this detestable mass murder" and how an "assassin"- possibly a state militiaman — had "amused himself" by shooting fleeing blacks at an intersection. While thus denouncing the violence, the paper claimed the causes of the rioting were clear:

The big slaughterhouses and other industrial plants in the city had, partly out of desire for profit and partly out of a wish to bully their white labor force, imported thousands of $\mathrm{Ne}$ groes from the South. These increasingly pushed the white man out of work, and, trusting in his superiority in numbers, the colored son of the South displayed an "independence" which he had not dared show in the South and which looks more like insolence and brazenness than anything else. The white man viewed the new competition in the workplace with unkind eyes..$^{51}$

Amerikanaren also devoted an editorial to the riots, repeating that they had their roots in labor-market competition where employers pitted one ethnic group against another. That, stressed the paper, was an explanation, however, and not an excuse. What had happened in East St. Louis, "in our own state," was a crime against civilization and would forever stain the history of Illinois. ${ }^{52}$

48 “Raskriget i Illinois," STN, 10 July 1917, 1.

49 “Inbördesfejd i Illinois," SK, 12 July 1917, 1.

50 "Negerblodbadet en följd af exploatering i arbetsmarknaden," SA, 12 July 1917, 10.

51 “Raskrig slutar med massaker," SA, 12 July 1917, 1.

52 “Raskrig," SA, 12 July 917, 4. 
As the fateful summer of 1919 began, it was evident that racial tensions were mounting in Chicago as well. In late June, Svenska Tribunen-Nyheter claimed that race war had broken out on the Southside:

The great Negro influx of the last few years into the city's various districts, particularly the one in the vicinity of Washington Park, has gradually given cause for discontent among the white population. Lately, it has happened on a couple of occasions that property owners who have rented apartments to Negroes have had their lives threatened and even been targets of malevolent acts of violence. ${ }^{53}$

A teacher who had sought to protect black children had been beaten, and at a confrontation between blacks and whites the previous weekend, one African-American had been killed and another severely wounded.

\section{Covering Riots}

While stories such as that published in Tribunen-Nyheter hinted at the conditions for Chicago's African-Americans and at a looming crisis, they were so infrequent in the three papers that they could not have prepared the readers of the city's Swedish-language press for the rioting that broke out in late July. In somewhat surprised tones, Svenska Amerikanaren's front page told of "murderous street riots on the Southside," and that of Svenska Kuriren of how "the racial hatred between blacks and whites has suddenly flared up in this city, with bloody riots and fights." ${ }^{54}$ To Kuriren, the unrest, still not under control when it and Amerikanaren went to press, even threatened "to gain the upper hand over order in the community."

While both Kuriren and Amerikanaren thus gave the riots front-page play and large headlines, Svenska Tribunen-Nyheter chose to run it in the Chicago department on page nine, alongside other, less dramatic, city news. Possibly bearing in mind its story back in June about the deadly confrontation in Washington Park, the paper called the August riots a "new" race war. ${ }^{55}$

Although the subsequent investigation by the Chicago Commission on Race Relations showed that white attacks on blacks were more common

53 “Raskrig på sydsidan,” STN, 25 June 1919, 10.

54 "Raskrig lågar upp"; "Blodigt raskrig," SK, 31 July 1919, 1.

55 "Ett nytt häftigt raskrig," STN, 30 July 1919, 9. 
than the reverse, the three Swedish papers tended to play up violence by African-Americans. A Chicago Swede who was killed during the riots had been a bystander at the intersection of Wabash and $35^{\text {th }}$ streets, according to Svenska Amerikanaren, where 50 police officers confronted " 2,000 Negroes" and where "gun shots were resounding and bricks flying every which way." ${ }^{56}$ Protected by a railroad embankment by $51^{\text {st }}$ Street, "a bunch of Negroes" had been firing randomly at pedestrians and trains, claimed the paper, and on Michigan Avenue, a black mob had stabbed a Greek peddler to death. ${ }^{57}$

When the next issues of the three papers appeared the following week, order had been restored, and articles focused on summing up the situation. ${ }^{58}$ "A terrible fire of hate" had gripped the city, thought Svenska Kuriren's editors, while Svenska Tribunen-Nyheter considered racial hatred a "consuming" fire that "long has smoldered beneath the ashes in this country and now and then has flared up." ${ }^{59}$ On its editorial page, Svenska Amerikanaren published a piece by "a friend of this newspaper" who unequivocally saw the unrest as the result of white aggression:

What we in Chicago have denounced the white population of the South for doing we have now ourselves done. The colored man and woman have been harassed, persecuted and killed for the sake of the color of their skin. The white man, who has a higher level of education, has brought to light more brutality than the savage. He has murdered, not in selfdefense, but out of thirst for blood, spite and hatred. The Negro has defended himself. ${ }^{60}$

However, white rioters were not the only ones who should shoulder the blame, according to the letter writer. Equally guilty were "the arch-profiteers in the guise of meatpackers who by hook or by crook have pulled more than 100,000 Negroes from the South to Chicago the last two years, without caring about where these children of the South should live." Amerikanaren commented that it shared most of the author's sentiments but thought he put too much blame on the whites, as "the blacks have to a high degree brought on what happened because of their provocative ways."

56 "Raskrig lågar upp."

57 Amerikanaren did note, however, that a white mob had attempted to storm the stockyards police station to get its hands on five African-Americans held there.

58 Tribunen-Nyheter was published on Wednesdays, Amerikanaren and Kuriren, Thursdays.

59 "Raskriget i Chicago," STN, 6 August 1919, 6; "Vildt utbrott af rashat," SK, 7 August 1919, 1.

60 “En fläckad sköld," SA, 7 August 1919, 4. 
From then on, the three papers occasionally followed the aftermath of the riots as it played out in court, and both Kuriren and Tribunen-Nyheter reported that the killing of a white man after an altercation with two blacks in September 1920 had almost led to "a new race war" but that police had been able to intervene. ${ }^{61}$ Their overall coverage of Chicago's African-Americans did not change, however, although they in their own comment during and before the unrest had pointed to issues such as overcrowded housing and racial conflict in the workplace. In the three large Swedish weeklies, blacks continued to appear in news stories only as murderers, armed robbers, and sexual predators. ${ }^{62}$

\section{Swedish-American Coverage in Context}

Giving readers the impression that blacks were criminals was not unique to Chicago's Swedish-language press. William Tuttle's comprehensive study of the 1919 riots stresses that the coverage of African-Americans in the city's English-language dailies overwhelmingly concerned crime, reinforcing white stereotypes of blacks as "immoral, emotional and criminal." 63 That portrayal, moreover, did not change after the riot. ${ }^{64}$ Tuttle's point is relevant because there was a direct connection between what appeared in the dailies and what found its way into the columns of the Swedish-language press. Devoting what meager staff resources they had to keeping track of events in the Swedish community in Chicago, the weeklies depended almost exclusively on the dailies for non-Swedish local news. "A weekly," stressed a 1910 inside account of Swedish-American journalism, "cannot afford to have reporters" and "[m]ost local news is, therefore, fetched from the large American daily newspapers." 65

Impressions conveyed by newspapers mattered, argues Tuttle, because white native-born Chicagoans had very little contact with African-Amer-

61 "Ett nytt raskrig," STN, 22 September 1920, 10; "En rasfejd," SK, 30 September 1920, 10; "Eko från raskriget," SA, 11 September 1919, 15; "Raskrigets följder," STN, 13 September 1919, 10; "Räfsten efter rasfejden," $S K, 25$ September 1919, 10.

62 "En mycket svart poliskonstapel," SK, 8 January 1920, 10; "Infångade af polisen," STN, 24 September 1919, 8; "Ett ohyggligt mord," SA, 1 January 1920, 15.

63 William M. Tuttle, Race Riot: Chicago in the Red Summer of 1919 (New York: Atheneum, 1978), 104.

64 Tuttle, Race Riot 1978, 250.

65 Alfred Söderström, "Nyhetsafdelningen," in Söderström, Blixtar på tidnings-horisonten (Warroad, MN: by the author, 1910), 168. 
icans because of the severity of housing segregation. Encounters between the two groups were confined to public transportation and to situations where blacks worked in menial occupations and whites were their customers. ${ }^{66}$ Swedish Chicagoans were in a similar situation, as the news items about Swedish and African-American encounters discussed above suggest. In contrast to Irish and Polish immigrants, who lived in areas bordering the black belt, Swedes had never settled in any great numbers in that part of the city. ${ }^{67}$ By the 1910 s, moreover, they had begun to leave the ethnic enclaves on the Northside where they had initially clustered in favor of the suburbs ${ }^{68}$ Commenting on a double murder in June 1915 , for instance, Svenska Amerikanaren noted that the Old Northside was a part of town "where in the past our countrymen could be found" but "where now thousands of Sicilians have put down stakes." ${ }^{69}$ The lack of personal contact with blacks among the readers of the three papers was reinforced by the scant appearance of African-Americans in the news; what glimpses the news afforded readers of black life tended portray African-Americans as criminal and thus reinforced stereotypes.

Such negative coverage in the papers' news columns was not uniquely reserved for African-Americans, however. Italians, the ethnic group that received the second largest share of coverage, were also portrayed as criminal and violent. As noted by Arnold Hirsch, Swedes, like Germans, were an "older" immigrant group that was regarded by American mainstream society as more "'desirable' and 'assimilable" than those from Central and Southern Europe, and coverage echoed that. ${ }^{70}$

It needs to be pointed out that the three Swedish weeklies also published items about Swedes who committed crimes. That kind of news, however, was more than balanced out by items about immigrants' personal achievements, activities of immigrant institutions such as churches and societies, and personal news such as birthday celebrations, weddings and births. Be-

66 Tuttle, Race Riot 1978 , 103-06.

67 Joseph Parot, "Ethnic versus Black Metropolis: The Origins of Polish-Black Housing Tensions in Chicago," Polish American Studies 29 (1/2, Spring-Autumn 1972): 27-28.

68 Anita R. Olson, “A Community Created: Chicago Swedes, 1880-1950," in Ethnic Chicago: A Multicultural Portrait, ed. by Melvin G. Holli and Peter d'A. Jones ( $4^{\text {th }}$ ed., Grand Rapids, MC: William B. Eerdmans Publishing Company, 1995), 111.

69 "Mord och hämd," SA, 17 June 1915, 15.

70 Hirsch, "E Pluribus Duo?: Thoughts on 'Whiteness' and Chicago's 'New' Immigration as a Transient Third Tier," Journal of American Ethnic History 23 (4, Summer 2004): 23-24. 
tween 1908 and 1910, for instance, the share in Svenska Amerikanaren of such news amounted to 79 percent, while items about crime and accidents involving Swedes was only 21 percent. ${ }^{71}$ While, as noted above, SwedishAmerican editors relied heavily on Chicago's dailies for news about the city, they found little news there about the community their readers belonged to and had by necessity to be more active in gathering news about that community, resulting in more nuanced coverage. They had neither the resources nor the inclination to go beyond the English-language press when it came to other ethnic communities.

It should be noted, finally, that the lack of interest Chicago's Swedishlanguage press showed towards the city's African-American community was, in a sense, reciprocal. During the time period discussed here, 19151919, the Broad Ax, a black weekly in Chicago, referred to Swedish-Americans in five items, two of which were jokes based on ethnic stereotypes. ${ }^{72}$ For all ethnic newspapers, the primary concern was with their own groups.

\section{Conclusion}

Just as Robert Zecker's study of the Slovak-American press showed, the three Swedish-language papers examined in this article paid attention to African-Americans, introducing race as an element of life in the new country of their readers. Addressing the questions posed in the introduction of this study, however, it is evident that coverage of blacks in Chicago hewed to stereotypes prevalent in American society at the time, portraying AfricanAmericans as criminal and prone to violence. As noted above, the similar coverage in the Swedish-language press and in Chicago's English-language dailies was not accidental, as the dailies were the main source of Chicago news that did not deal with the local Swedish community.

When it came conveying to readers that African-Americans were settling in Chicago in record numbers and that this influx was causing tensions, the three weeklies clearly fell short, as only a handful of items hinted at the rapid growth of the city's black population. Again, the editors of Ameri-

71 Percentages are based on a sample of four issues per year for 1908, 1909, and 1910 .

72 "Hon. Julius Johnson Republican Candidate for the Nomination of Auditor of Public Accounts for the State of Illinois," Broad Ax (hereafter, BA), 1 July 1916, 5; “An Irresistible Call," BA, 21 April 1917,4; "Col. R.S.Abbott," BA, 17 November 1917, 1; "Swedish League Heads Back Congressman McCormick," BA, 15 June 1919, 2; "Nostalgia,” BA, 12 July 1919,2 . 
kanaren, Tribunen-Nyheter and Kuriren appeared in that respect to have taken their lead from the Chicago daily press, which also more or less ignored the Great Migration. 